\title{
Theoretical Research and Prospect of the Impact of Government Intervention on M \& A
}

\author{
Qi Gao \\ School of Economics \& Management \\ Nanjing University of Science and Technology \\ Nanjing, China
}

\begin{abstract}
Through the study of relevant theories and literatures, this paper describes the impact of government intervention on the impact of mergers and acquisitions based on the government regulation theory, ownership concentration theory and the ultimate control theory. Related theories are relatively fragmented and lack of systematic. Through the comparison of USA and China, this paper makes some suggestions for the future research of emerging market government intervention policies and measures.
\end{abstract}

Keywords -mergers and acquisitions; government intervention; regulatory theory; ownership concentration theory; ultimate control

\section{INTRODUCTION}

Both Keynes and Adam Smith argue that government intervention plays an important role in the market. Nowadays, many countries use their power to intervene in corporate mergers and acquisitions. The essence of government intervention changed from "Futile Hand", "Helping Hand" to "Grabbing Hand". Under the guidance of this theory, government intervention in corporate mergers and acquisitions went through the process of "laissez faire, regulation, deregulation, and re-regulation". Relevant researches and theories are related to government regulation theory, state intervention theory, political science and other areas. But those studies are fragmented, especially in the transition economies. Therefore, it is necessary to summarize the research results of "motivation and effect of government intervention in enterprise acquisition", and this can provide reference for government intervention.

\section{THEORETICAL RESEARCH OF MOTIVATION OF M \& A}

There are a lot of literatures about the motives of mergers and acquisitions, and the theoretical system is relatively complete. At present, there are five major theories to explain the $\mathrm{M} \& \mathrm{~A}$ (mergers and acquisitions) motivation from different angles "Fig. 1". The synergistic effect is the combined benefits of the combined effect of the two companies over the expected benefits of their independence [1]. It shows the reallocation of capital between the two sides of the capital [2]. Transaction cost theory pointed out that mergers and acquisitions can reduce transaction costs and improve business efficiency. Principle-agent theory argues that the stock price is related to the company's management level and the $M$ \& A will happen when the stock price is low [3]. It shows that M \& A can improve the management. Holderness and Sheehan's research shows that when the acquirers find that when the target company cannot play its firm potential due to management efficiency and other reasons, the market price is lower than it should reach. They have enough motivations to acquire the target company stock at this low price. The performance of the target company enhances through business integration and other methods, so that its share price rose and thus gets profit [4]. Bradley, Diesel and Kim (1983, 1988) conducted empirical studies based on related data. Their study results showed that within 5 years after the first acquisition failed, if the target company no longer received the takeover offer, its share price fell back to the original level. On the other hand, if the target company received new bid offers, its share price rose further. They said that this research suggested that new information is generated because of the tender offer and the hypothesis that "Revaluation is a permanent" is ineffective [5]. The permanent revaluation of the target company's share price will only occur in a few cases. According to their research, empirical evidence is consistent with synergistic interpretation. The acquisition does not necessarily mean that the target company's share price is underestimated by the market or the target company can use its own strength to improve management. The manager's pay is dependent on the size of the company, so the manager has a strong desire to expand the size of the company [6]. Executives are risk averse, and their pursuit of size allows their compensation groups to be separated to the greatest extent possible, and then linked to relatively stable corporate scale factors to reduce their own risk of compensation [7]. Both in developed countries and emerging markets, motivations of $\mathrm{M} \& \mathrm{~A}$ are comprehensive and diverse.

\section{RESEARCH BASED ON GOVERNMENT REGULATION THEORY}

In the west, regulatory economics is the basic theory to explain why government intervene $\mathrm{M} \& \mathrm{~A}$ in market economies. Government regulation theory has experienced the rules of Public interest theory, Group interest theory of regulation, Incentive regulation theory, and brings different regulatory effects. 


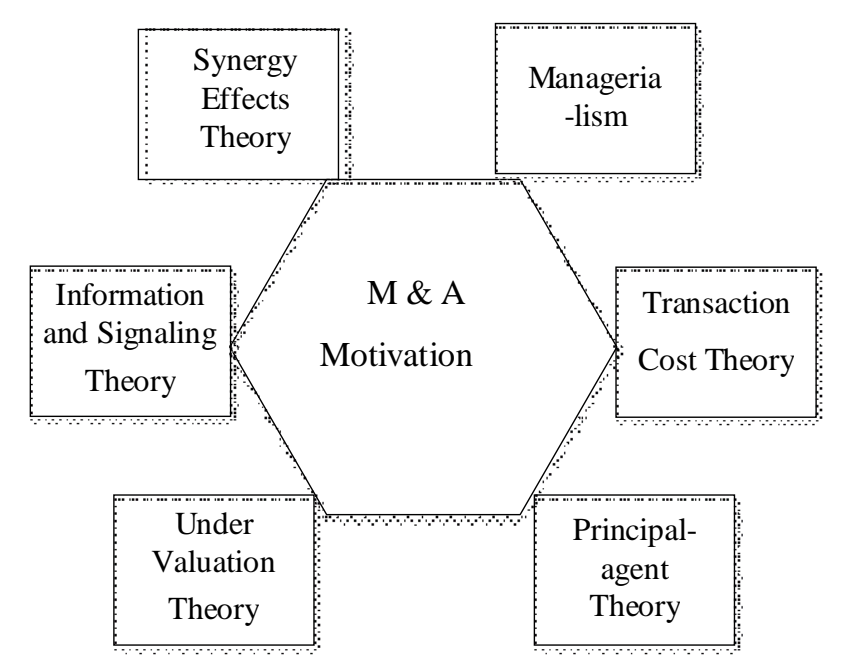

Fig. 1. Theoretical system of M \& A Motivation

\section{A. Public Interest Theory}

In 1968, Bain created the SCP analysis paradigm (Structure-Conduct Performance Paradigm). The SCP proved that market concentration would lead to an oligopolistic market structure that would lead to oligopolistic market behavior that ultimately led to market inefficiencies and overall social welfare losses [8]. Therefore, the government should strictly control or even split the mergers and acquisitions, to reduce the possible market failure brought about by M \& A. The empirical results show that SOE acquirers outperform POE acquirers in terms of long-run stock performance and operating performance [9].

However, many practices have proved that government regulation is not entirely effective, severe anti-monopoly policy not only did not solve the market failure, but brought the indirect effect of undesirable: Firstly, it suppressed the development of efficient large enterprises, leading to economic downturn and corporate competitiveness decline in the 70's US. Secondly, the concentration of many industries was still improving, it means that strict anti-monopoly regulation did not reverse this trend. The public interest theory of regulation points out the necessity of government intervention in mergers and acquisitions and guides the government to correct some market failures and unfair behavior in $M \& A$. But the three prerequisites of the theory-regulatory agencies have complete information, full commitment capacity and work for the benefit of the community - have been proved that no one can be fully satisfied in the reality; In addition, there are serious shortcomings in the SCP paradigm. There are many problems that can refute it in practice, and the regulation effect is unsatisfactory. The theory has been criticized by scholars and directly led to the appearance of Group interest theory of regulation.

\section{B. Group Interest Theory}

In 1971, Stigler incorporated political action into the framework of Supply-demand analysis of economics, then created interest group regulation theory [10]. In this theory, the politician is a "economic man" with a variety of "selfish" motives that can rationally maximize his own interest. Interest groups improve the welfare of the group by providing what politicians need (such as political support, bribery) to persuade the government to implement self-interest policies. government interventions in the banking sector deteriorate the credit risk of sovereign debt [11]. Because of the existence of rent-seeking government regulation will distort the market efficiency [12]. More specifically, government regulation cannot solve the problem of unfair competition, and it is against the increase of efficiency. So, regulation should not be implemented on corporate mergers and acquisitions.

Group interest theory of regulation seems to be more reasonable and profound to assume that government is a "economic man". However, the static analysis method and market self-improvement hypothesis of the Chicago school lead to the one-sidedness of its theoretical derivation and conclusion, and its policy of competition substitution regulation has repeatedly been questioned and challenged in the practice of mergers and acquisitions. At the same time, from the perspective of interests, it cannot fully explain the behavior that government put public interest above the interests of various groups.

\section{Incentive Regulation Theory}

Since the 1980s, Incentive regulation theory, which fully considered that the information is not sufficient and market is not complete, has brought a revolutionary breakthrough to Regulatory Economics. Incentive regulation theory absorbs lasted achievements in microeconomics such as Information Economics and Incentive theory and argues that under the condition of information asymmetry, the regulation problem is essentially an incentive problem in the Principal-agent Theory. Although the perspective of government regulation research has changed from "why regulation" to "how to regulate", this change implied the motives of government regulation: First, the government regulation seeks for public interest. After introducing the Game Theory and incomplete information, Laffont and Tirole [13] pointed out that due to the existence of information asymmetry, sunk costs, network externalities, etc., enterprises will carry out some strategic behaviors (such as Barriers to entry, Tacit Collusion) to change the market environment and squeeze out the competition. Thus, the market is largely imperfect, and there is a market failure, so government regulation is indispensable. The government's task is to give full play to the market's incentive and resource allocation function and build enterprise incentive contract to maximize the social welfare [14]. Second, the government is a representative of special interest groups. Based on adhering to the motives of government groups' interests, the follow study of Laffont and Tirole [15] absorbed the non-holistic view of the regulatory system at the frontiers of political science, dividing the regulatory agencies into regulators (supervisors) and congresses (clients). Laffont argued that regulators are selfserving "economic person", so regulators may be used by enterprises or interest groups, thus he developed a three-tier structure of principal-agent theory of the interests groupconsidering the incentive to the regulated enterprises, the theory emphasizes constraints and control to regulators. 


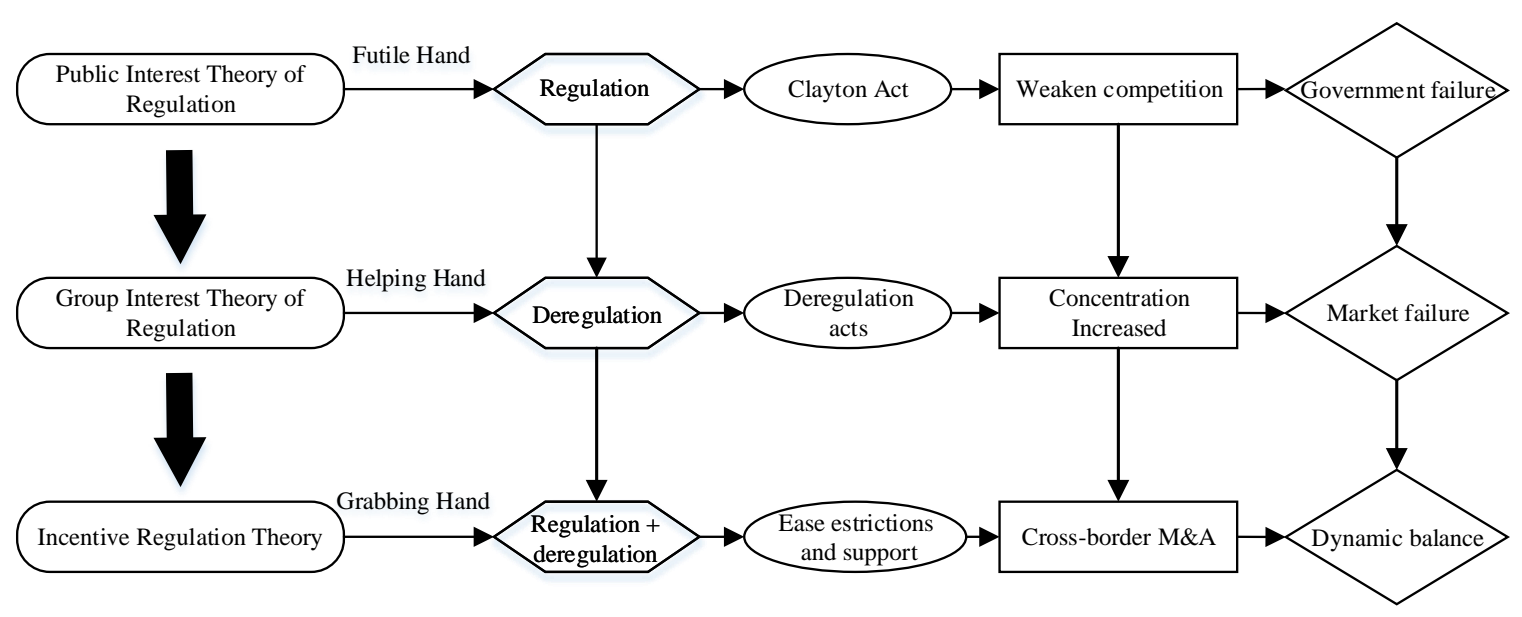

Fig.2 The Evolution of Theory and Effect of Government Intervention in M\&A

Incentive regulation theory has revised the shortcomings of traditional regulation theory to a certain extent, and realized the integration of government regulation theory of Public interest theory and Group interest theory. But it is not simply a revitalization to the Harvard School's strict interventionism, it is still convinced that the power of the market is more effective than the regulatory policy; the government intervention is only for the market to run more effectively. Although the Game theory model provided by this theory is very close to the complex behavior of enterprises, there are some difficult to overcome defects in its overly fine assumptions, complex and profound mathematical model and the tool itself. It is difficult to really play a useful role in the research and practical application of practical problems which is directly related to regulatory policies. At present, there is not enough empirical analysis to verify whether it is useful.

Under the influence of incentive regulation, governments have strengthened the "re-regulation" of corporate mergers, changed their loose regulatory stance, and turned to prudent and moderate intervention [16].

As shown in "Fig. 2", regulatory economics reveals the evolution of government intervention in corporate mergers and acquisitions.

\section{RESEARCHES ON THE OWNERSHIP CONCENTRATION THEORY}

In china, government holds absolute control of the Stateowned enterprise. Scholars explored the effect of government intervention in mergers and acquisitions based on empirical study on the impact of state-owned share on $M \& A$ performance and then revealed the motives of government intervention in mergers and acquisitions. According to ownership concentration theory, the major shareholders will implement the tunneling behavior only considering maximizing their own welfare [17]. But it may also reduce the interests of the infringement and conducive to the improvement of corporate value because of the supervision of large shareholders on the management effect. Government interventions affect corporate policies differently and have opposite effects on financing policies: while firms with higher level of government ownership tend to use higher leverage, more long-term debt and hold less cash [18]. Researchers found that the proportion of the largest shareholder is positively correlated with the performance of $\mathrm{M} \& \mathrm{~A}$, but is significantly negative with the impact on long-term $M$ \& A performance [19]. Many M \& A contrary to the wishes of enterprises, not only failed to manage the loss of enterprises, but also dragged the advantages of enterprises and distort the allocation of resources. However, more scholars have confirmed that the impact of state ownership on corporate mergers and acquisitions has a two-sided nature. It is possible to seize corporate wealth through political intervention, or to increase corporate value through corporate governance and preferential treatment [20]. Blanchard and Shleifer also pointed that one of the important reasons for difference of economic growth between China and Russia since 1989 is the quality of the government [21]. Therefore, both grabbing effect and helping effect coexist in the government intervention $\mathrm{M} \& \mathrm{~A}$ form the enterprise. However, scholars generally recognized that the goal of government intervention in mergers and acquisitions is to achieve a variety of public governance objectives from the effect of macroeconomic intervention. Thus, even if there is administrative intervention by the government regardless of the interests of the enterprise, its motive is still to maximize the pursuit of social welfare "Fig. 3".

Most scholars just inferred the motivations of intervention through the empirical results of government holding and intervention. They didn't establish a standardized economic theory model to analyze the government intervention and analysis of the formation of government action mechanism based on the perspective of political science, resulting that the reality of the existence of government mergers and acquisitions of private interest cannot be explained reasonably. 


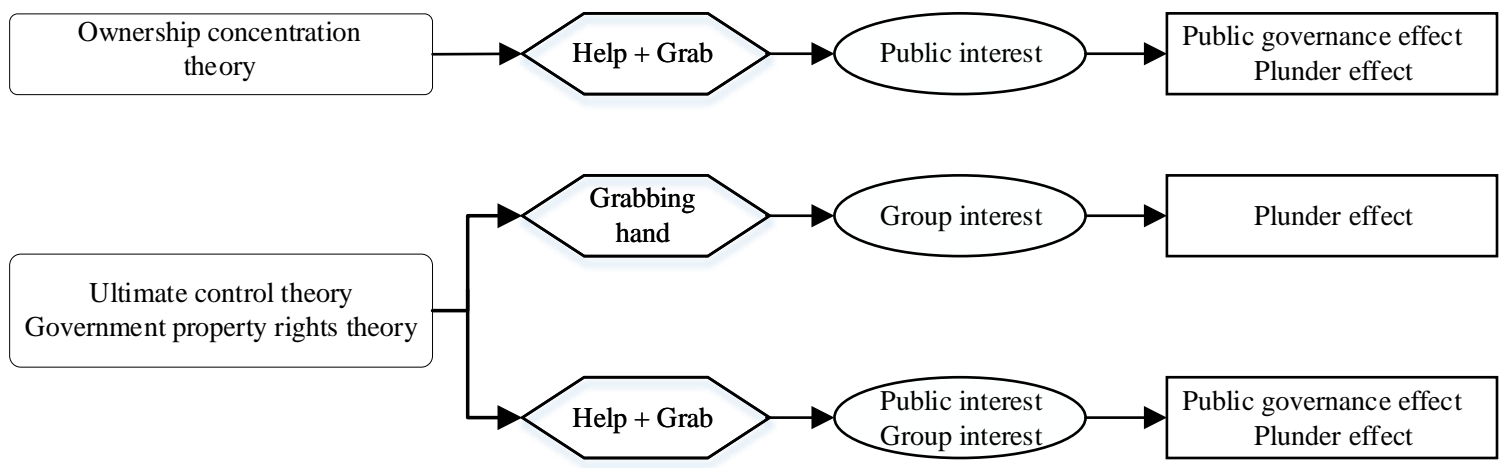

Fig.3 The Evolution of Effect of Government Intervention in M\&A with Ownership concentration theory and Ultimate control theory

\section{RESEARCHES ON THE THEORY OF ULTIMATE CONTROL OF GOVERNMENT}

In recent years, Ultimate control theory pioneered by La Porta has provided a new perspective for the study of government intervention in transitional economy [22]. Based on the Ultimate control theory, Shleifer proposed different views about the motives of the government intervention [23]. After the study of transition that happened in some transition countries (Eastern European countries and Russia), Shleifer found that when government gain the ownership and control of enterprises to effectively control enterprise through pyramid control, cross-shareholding and other methods, government has become the ultimate controlling shareholder of the enterprise [24]. Government not only provides regulation and guidance for $\mathrm{M} \& \mathrm{~A}$ but also determines the decision of the enterprise $\mathrm{M}$ $\& \mathrm{~A}$ as the ultimate shareholder [25]. The government has a lot of social responsibilities and motives and abilities to impose its social goals on the enterprise naturally [26]. Many scholars have proved that the phenomenon of Ultimate Control of Government is remarkable in developed economies (such as Finland, Norway, France, Japan, Singapore and other countries), emerging economies (such as India, Malaysia, the Philippines and other countries) and transition economies (such as China, Hungary, Russia, Czech and Slovakia and other countries) [27]. Shleifer and Vishny created a series of "grabbing hand" models including rent-seeking models, corruption models, privatization models and game models between politicians and businesses, demonstrating that in the context of lack of external checks and balances and other shareholders' supervision, the goal of government intervention to use government-controlled property to pursue the maximization of the interests of politicians or groups. Only when the political interests of the government coincide with the social welfare, social welfare will be improved.

From the term of effect of intervention, the government will intervene $\mathrm{M} \& \mathrm{~A}$ to pursue its political goals (such as rentseeking, encouraging employees to hire surplus employees and seeking political support) which will result in enterprise do not target the maximizing value and resulting in "plunder" effect [28]. The motivation of government support business is implementing tunneling behavior in the future even though it will implement countervailing and carry out the interests of the company [29]. Government behavior has brought inefficiency or low efficiency of resource redistribution and $M \& A$, and induced the government's political association, bribery and other actions that would lead to huge losses of social efficiency and economic slowdown. Shleifer also points that government property under the socialist system has greater power and greater damage to the economy than the capitalist system.

Ultimate controlling theory argues that the reform must meet the political interests and constraints, as much as possible to reduce the damage to government failure. This considerate the real political environment of the government's ultimate holding area in a deeper extent. However, the theory of ultimate control of the government is mainly based on empirical research, and the theoretical analysis of normative economics is relatively inadequate. Complete theoretical system is not built for the internal mechanism of intervention and the transmission mechanism. At the same time, only recognizing the government's selfish motives are biased is not entirely in line with the reality.

Theory of Ultimate control of government is more suitable for the actual situation of China under the socialist system. A series of case studies show that government intervention in mergers and acquisitions is related to the personal goals of government officials, such as the promotion of posts, the stability of power, the power of resources and gray income [30]. The theory believes the government intervention based on group interests is a grabbing hand and cannot help the company achieve long-term improvement. Peng et al. [31] demonstrated that the government would actively support its holding companies to maintain "shell" resources and obtain refinancing qualifications, but the support is usually followed by more serious emptying. From the view of macroeconomic point, although the government intervention is to achieve the structural adjustment and solve the employment problem, the local government just wants to obtain the promotion of the performance of the project. It contributed to the government rent, rent-seeking and other acts of corruption instead of conducing to the rational allocation of resources and efficiency [32]. Xia Lijun and Fang Yiqiang [33], Pan Hongbo et al [34] distinguish differences of intervention motive between the central government and local government. They pointed out that the purpose of local government intervention in corporate mergers and acquisitions is to achieve the personal goals of government officials or group interests through empirical research. Central government's intervention in corporate mergers and acquisitions is more from the development of 
macroeconomic public interest motives because of greater emphasis on macroeconomic development of the public interest and overall interests. Zhang Weidong et al. [35] argued that the plundering and supportive effects of government intervention should coexist, and Pan Hongbo and Yu Minggui [36] furtherly pointed that the support effect of government intervention should be dominant. With the tilt of local officials' performance evaluation to regional public governance, the personal objective function of local officials and the overall development of regional economy are becoming more and more consistent, and government intervention in enterprise mergers and acquisitions will gradually be standardized. It will be conducive to the overall development of regional economy [37].

China's empirical research results argue that the different levels of government have different target structure. Group interests and public interest motive coexist. Grabbing hand and helping hand coexist. It broadened the conclusion of Shleifer, but its research methods are still limited to case studies or variables, and the analysis of normative economics is relatively inadequate.

"Fig. 3" shows the evolution of the motivations and effects of government intervention in $\mathrm{M} \& \mathrm{~A}$ under Ownership concentration theory and Ultimate control theory. economic liberalism and government interventionism. Table I shows the progress of government intervention in this two countries.

The intervention of the US government on corporate mergers and acquisitions is mainly reflected in the two aspects: restriction and support. On the one hand, taking restrictive measures on those who hinder the fair competition in society order to properly protect the interests of stakeholders through the anti-monopoly law, resulting in social welfare loss of M \& A. On the other hand, for the sake of economic development, the government has adjusted measures in legislation from time to time to support mergers and acquisitions that are conducive to economic development. The government intervention in the United States emphasizes the application of legislation and economic leverage to indirectly guide corporate mergers and acquisitions, rather than direct interference. The Chinese government often intervenes in mergers and acquisitions as a state-owned asset agent. On the one hand, it promotes corporate $\mathrm{M} \& \mathrm{~A}$, enhances the competitiveness of enterprises and reduces the number of loss-making enterprises through the allocation of assets and other ways. On the other hand, it uses social management functions to manage corporate mergers and acquisitions, to resolve conflicts of interest and protect the interests of countries and businesses.

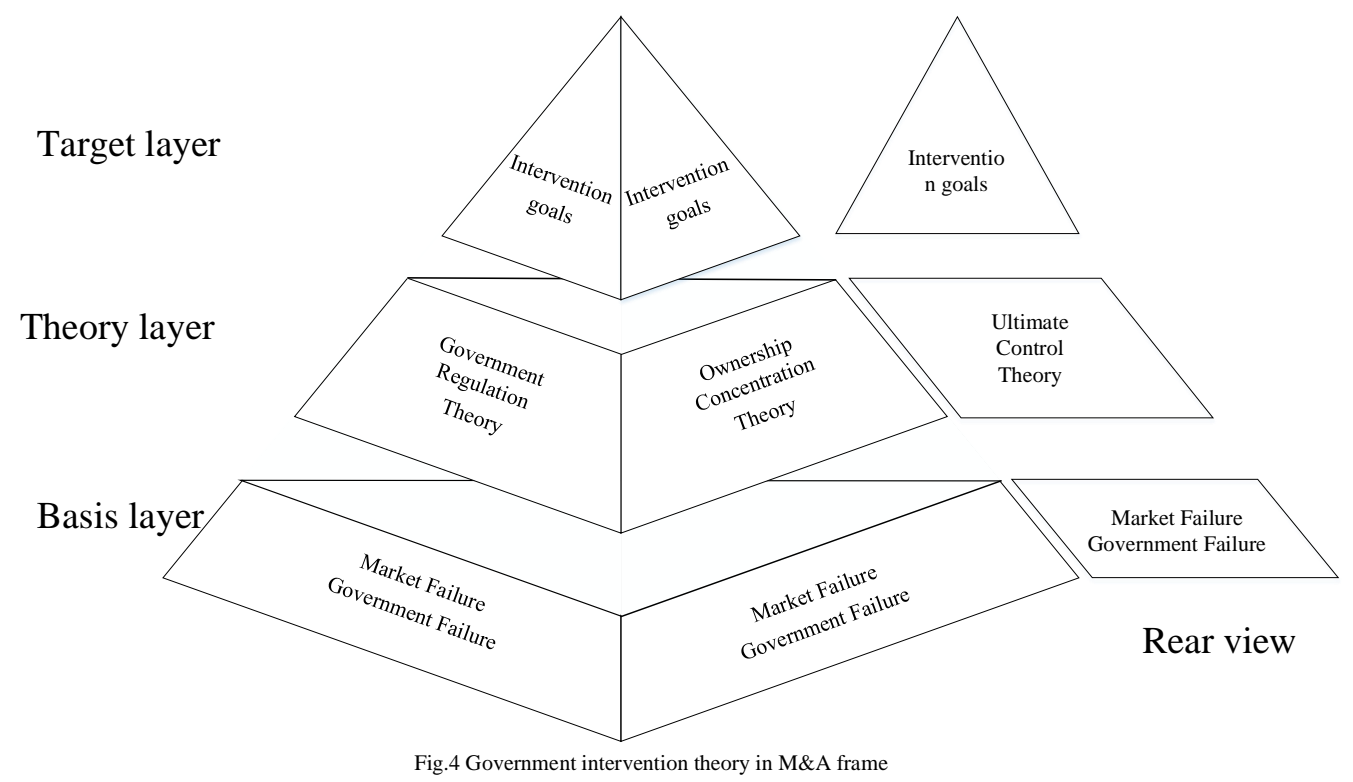

"Fig. 4" shows the government intervention theory frame in M \& A.

TABLE I. GOVERNMENT INTERVENTION PROCESS IN USA AND CHINA

Research on the Comparison of Government Intervention in $M \& A$ between usa and china

Mergers and acquisitions in USA are the most typical in the western. USA has the most prosperous economy and M \& A activity is the most active, several major waves of mergers and acquisitions are caused by it. China's government intervention is different from the USA. The government promulgated laws, regulations and policy measures to manage corporate mergers and acquisitions, rather than a special system of corporate mergers and acquisitions. As the world's first and second largest economy, the USA and China are representatives of

\begin{tabular}{|l|l|l|}
\hline Nation & \multicolumn{1}{|c|}{ Time } & \multicolumn{1}{c|}{ Feature } \\
\hline \multirow{5}{*}{ USA } & $1890 \mathrm{~s}$ & No intervention \\
\cline { 2 - 3 } & $1920 \mathrm{~s}$ & Limit horizontal mergers \\
\cline { 2 - 3 } & $1950 \mathrm{~s}$ & Limit horizontal and vertical mergers \\
\cline { 2 - 3 } & $1970 \mathrm{~s}$ & Deregulation \\
\cline { 2 - 3 } & $1994-2016$ & $\begin{array}{l}\text { No limit } \\
\text { Encourage and support M \& A }\end{array}$ \\
\hline \multirow{5}{*}{ China } & $1984-1987$ & $\begin{array}{l}\text { Government-led } \\
\text { Administrative coercion }\end{array}$ \\
\cline { 2 - 4 } & $1988-1992$ & Government-led \\
\cline { 2 - 3 } & $1992-2001$ & $\begin{array}{l}\text { Government-led reduced } \\
\text { Market-led increased }\end{array}$ \\
\cline { 2 - 3 } & $2002-2016$ & Government\&Market-led \\
\hline
\end{tabular}




\section{CONCLUSION}

From the macroscopic perspective, the government regulation theory went through the Public interest theory, Group interest theory, and Incentive regulation theory and achieved integration of the public interest motive and group interest motivation. From the microcosmic perspective, theory of Ultimate Control regards government intervention as an endogenous variable in corporate mergers and acquisitions that is for the realization of private interests, and brought a series of "plunder" effect resulting in huge loss of efficiency. Research in this area is still facing new challenges in research content and research methods. Related theories are relatively fragmented and lack of systematic. The government regulation theory focus on the macroscopic perspective and the ultimate control theory focus on the microcosmic perspective. They lack relevance with each other so the researchers can consider integrating them into a system in the future. Studies on emerging market are too few. The government regulation theory is based on the western market and cannot explain the problem of emerging market. The ultimate control theory provides a new perspective for the research in the transition economy, but the mechanism still lacks systematic and in-depth research on the mechanism of government intervention in mergers and acquisitions. The relationship between the equity structure and the value of the firm should be complex, comprehensive. The problem need to be solved in the future that what kind of mechanism does government shareholders influence the behavior of $\mathrm{M} \& \mathrm{~A}$ and how to realize the pursuit of control right in $\mathrm{M} \& \mathrm{~A}$.

Based on the analysis of this paper, the countries with emerging markets has some directions of reform in the future. Mergers and acquisitions ultimately rely on the main market behavior to achieve. It is necessary to improve the market mechanism and take full advantage of the regulatory role of the market. The self-interest motives of government departments and the motivations of government officials need to be eliminated. It also need to establish a sound supervision mechanism and regulate the rules of the market.

\section{ACKNOWLEDGMENT}

Many people have offered me valuable help. I would like to express my gratitude to all those who helped me during the writing of this thesis.

\section{REFERENCES}

[1] Sirower, MARK L., and RICHARD D. Stark. "The PMI board pack: New diligence in M \& A." DIRECTORS AND BOARDS-AMERICAN EDITION- 25.4 (2001): 34-39.

[2] Dongpo Huang."Research on M \& A Motivation."Communication of Finance and Accounting(2008):90-92.I.S. Jacobs and C.P. Bean, "Fine particles, thin films and exchange anisotropy," in Magnetism, vol. III, G.T. Rado and H. Suhl, Eds. New York: Academic, 1963, pp. 271-350.

[3] Fama, Eugene F., and Michael C. Jensen. "Separation of ownership and control." The journal of law and Economics 26.2 (1983): 301-325.

[4] Holderness, Clifford G., and Dennis P. Sheehan. "Raiders or saviors? The evidence on six controversial investors." Journal of Financial Economics 14.4 (1985): 555.

[5] Bradley, Michael, Anand Desai, and E. Han Kim. "Synergistic gains from corporate acquisitions and their division between the stockholders of target and acquiring firms." Journal of financial Economics 21.1 (1988): 3-40.

[6] Mueller, Dennis C. "A theory of conglomerate mergers." The Quarterly Journal of Economics 83.4 (1969): 643-659.

[7] Kroll, Mark, Peter Wright, and Pochera Theerathorn. "Whose interests do hired top managers pursue? An examination of select mutual and stock life insurers." Journal of Business Research 26.2 (1993): 133-148.

[8] Bain Joe S. "Industrial organization." 2nd ed.New York: John Wiley \& Sons(1968):7-11.

[9] Zhou, Bilei, et al. "Does state ownership drive M \& A performance? Evidence from China." European Financial Management 21.1 (2015): 79-105.

[10] Stigler, George J. "The theory of economic regulation." The Bell journal of economics and management science (1971): 3-21.

[11] Kizys, Renatas, Nikos Paltalidis, and Konstantinos Vergos. "The quest for banking stability in the euro area: The role of government interventions." Journal of International Financial Markets, Institutions and Money 40 (2016): 111-133.

[12] Baumol, William J., John C. Panzar, and Robert D. Willig. "Contestable markets: An uprising in the theory of industry structure: Reply." The American Economic Review 73.3 (1983): 491-496.

[13] Laffont, Jean-Jacques, and Jean Tirole. "Using cost observation to regulate firms." Journal of political Economy 94.3, Part 1 (1986): 614641.

[14] Compte, Olivier, and Philippe Jehiel. "Gathering information before signing a contract: A screening perspective." International Journal of Industrial Organization 26.1 (2008): 206-212.

[15] Laffont, Jean-Jacques, and Jean Tirole. "The politics of government decision-making: A theory of regulatory capture." The Quarterly Journal of Economics 106.4 (1991): 1089-1127.

[16] Shapiro, Carl. "The 2010 horizontal merger guidelines: From hedgehog to fox in forty years." Antitrust Law Journal 77.1 (2010): 49-107.

[17] Edwards, Jeremy SS, and Alfons J. Weichenrieder. "Ownership concentration and share valuation." German Economic Review 5.2 (2004): 143-171.

[18] Shao, Yingying, Rodrigo Hernández, and Pu Liu. "Government intervention and corporate policies: Evidence from China." Journal of Business Research 68.6 (2015): 1205-1215.

[19] Congyin Wan, Jin Guo. "The Effect of Ownership Structure on M \& A Performance Based on the Effect of Enterprise Scale Adjustment-- From Shanghai and Shenzhen A stock market empirical evidence" Journal of Financial Research 9(2009):123-134.

[20] Lihui Tian. " Two Hands of the Government Shareholder and the U Curve between Government Shareholdings and Corporate Value." Economic Research Journal 10 (2005): 48-58.

[21] Blanchard, Olivier, and Andrei Shleifer. "Federalism with and without political centralization: China versus Russia." IMF Economic Review 48.1 (2001): 171-179.

[22] Shleifer, Andrei, R. La Porta, and F. Lopez-De-Silanes. "Corporate ownership around the world." Journal of Finance 54.2 (1999): 471-517.

[23] Shleifer, Andrei, and Robert W. Vishny. "Politicians and firms." The Quarterly Journal of Economics 109.4 (1994): 995-1025.

[24] Frye, Timothy, and Andrei Shleifer. The invisible hand and the grabbing hand. No. w5856. National Bureau of Economic Research, 1996.

[25] Chernykh, Lucy. "Ultimate ownership and control in Russia." Journal of Financial Economics 88.1 (2008): 169-192.

[26] Boubakri, Narjess, et al. "The political economy of residual state ownership in privatized firms: Evidence from emerging markets." Journal of Corporate Finance 17.2 (2011): 244-258.

[27] Faccio, Mara, and Larry HP Lang. "The ultimate ownership of Western European corporations." Journal of financial economics 65.3 (2002): 365-395.

[28] Shleifer, Andrei, and Daniel Treisman. Without a map: Political tactics and economic reform in Russia. MIT Press, 2000.:123-129.

[29] Riyanto, Yohanes E. and Linda A. Toolsema. "Tunneling and propping: A justification for pyramidal ownership." Journal of Banking \& Finance 32.10 (2008): 2178-2187. 
[30] Jinsong Tan, Bingqi Liu."Enterprise Merger:the Multipartite Games for Benefits Led by the Government."Management World. 2 (2005): 118132.

[31] Peng, Winnie Qian, KC John Wei, and Zhishu Yang. "Tunneling or propping: Evidence from connected transactions in China." Journal of Corporate Finance 17.2 (2011): 306-325.

[32] Minggui Yu, Puya Hui, Hongbo Pan. "Political Connections, Rent Seeking ,and the Fiscal Subsidy Efficiency of Local Governments" Economic Research Journal 45.3 (2010): 65-77.

[33] Lijun Xia, Yiqiang Fang. “Government Control , Institutional Environment and Firm Value: Evidence from the Chinese Securities Market" Economic Research Journal 5 (2005): 40-51.

[34] Hongbo Pan, Xinping Xia, Minggui Yu P. "Government Intervention, Political Connections and the Mergers of Local Government-Controlled Enterprises" Economic Research Journal 4.4 (2008): 41-53.

[35] Weidong Zhang." Government Intervention and Large Shareholder's Asset Injection: Propping or Tunneling" Accounting Research 8 (2012): 34-40.

[36] Hongbo Pan, Minggui Yu P. “Helping Hand, Grabbing Hand and Inter-province Mergers” Economic Research Journal. 9 (2011): 108120.

[37] Jinsong Tan, Guojian Zheng." The Public Governance of Local Governments and the Transfer of the Control Right of the State-owned Listed Companies."Management World. 10 (2009): 135-151. 